\title{
Why Internalists about Reasons Should be Humeans about Motivation
}

in Hume on Motivation and Virtue

Charles Pigden (ed.), Macmillan 2009. 


\section{Introduction}

In his paper 'Internal and External Reasons’ Bernard Williams suggests that internalism about reasons for action is compatible with the idea that beliefs are capable of motivating in their own right; i.e. that internalism is compatible with cognitivism about motivation. However, contrary to Williams’ suggestion, I will argue that internalists about reasons are in fact committed to a broadly Humean (noncognitive) theory about motivation and that internalists about reasons cannot allow that beliefs can motivate in their own right. Since I believe that Humeanism about motivation is false, I think internalism about reasons implies something false, and that therefore internalism about reasons should be rejected. In this paper I shall say nothing about why I think Humeanism is false; rather, my aim will be to establish that internalism about reasons is compatible only with (or makes sense only on) a Humean theory of motivation. To do this, I will try to show that the conjunction of cognitivism about motivation and internalism about reasons is, at best, an unstable position.

\section{Humeanism and Internalism}

Although there are different versions of internalism and 'the internal interpretation' of statements like 'A has a normative reason to $\phi$ ', Williams' claim that

any model for the internal interpretation must display a relativity of the reasons statement to the agent's subjective motivational set... (Williams, 1981, p 102.) ${ }^{1}$

seems to be central to all versions of internalism. According to internalists, a reason statement about an agent is falsified by the absence of some suitable element in that agent's subjective motivational set, where this set includes such things as 'dispositions of evaluation, patterns of emotional reaction, personal loyalties, and various projects, as they may be abstractly called, embodying commitments of the agent.' (Ibid. p, 105.) Externalists about normative reasons for action deny that an agent's reasons must be relative to his motivational set in this way. According to one 
influential version of internalism about reasons for action (which I will call 'motivational internalism')

(MI): A has reason to $\phi$ if and only if (and because) A is, or would be,
motivated to $\phi$ after having deliberated soundly on all relevant facts.

This model says nothing about what it takes for an agent to be motivated, and as such it seems neutral with respect to non-cognitivist and cognitivist theories of motivation. For MI to be plausible, however, and as Williams of course recognises, the reasongenerating power of an agent's motivations must be subject to what I will call the '(no reasons from) false beliefs’ proviso:

(FB): $\quad$ 'A member of [an agent's subjective motivational set] $S, D$, will not give $A$ a reason for $\phi$-ing if either the existence of $D$ is dependent on false belief, or if $A$ 's belief in the relevance of $\phi$-ing to the satisfaction of $D$ is false.' (Ibid. p, 103)

In other words, if an agent's motivation to $\phi$ is dependent on a false belief, then, ceteris paribus, it is not true of that agent that he has a reason to $\phi$. This, I take it, is common ground between internalists and externalists.

Although Williams’ internalism about normative reasons has traditionally been viewed as a paradigmatically 'desire-based' theory of reasons, in a much overlooked passage in 'Internal and External Reasons', Williams says:

Does believing that a particular consideration is a reason to act in a particular way provide, or indeed constitute, a motivation to act? ... Let us grant that it does - this claim indeed seems plausible, so long at least as the connexion between such beliefs and the disposition to act is not tightened to that unnecessary degree which excludes akrasia. The claim is in fact so 
plausible, that this agent, with this belief, appears to be one about whom, now, an internal reason statement could truly be made: he is one with an appropriate motivation in his S.(Ibid. p, 107. Italics added.)

It seems Williams is here suggesting that $\mathrm{MI}$ is compatible with cognitivism about motivation (CM) - compatible, that is, with the view that beliefs can motivate. Let us call this MI+CM. This view is incompatible with the familiar non-cognitive (Humean) theory of motivation. According to this theory

(H):

$$
\begin{aligned}
& \text { Beliefs are, by themselves, incapable of motivating an agent; only } \\
& \text { when an agent's beliefs are combined with some suitable desire (or } \\
& \text { other non-cognitive state) will he or she be motivated to act. }
\end{aligned}
$$

Cognitivists reject the idea that desires play this central role in motivation. According to cognitivists, at least some beliefs are capable of motivating in their own right (normative and evaluative beliefs are traditional candidates). While some cognitivists agree that the presence of a desire is indeed necessary for motivation, the necessity involved need not be a causal one. As Nagel puts it: 'That I have the appropriate desire simply follows from the fact that [my beliefs] motivate me.' (Nagel, p. 29.) So even if a desire is always present whenever an agent is motivated, this desire need not play the role Hume assigned it. On this understanding of the distinction between cognitivism and non-cognitivism in the theory of motivation, MI certainly seems compatible with CM.

\section{Beliefs and motivation}

According to MI+CM, then, A's belief [that $\mathrm{p}$ ] is a member of A's subjective motivational set if A's belief that $\mathrm{p}$ has motivational force. ${ }^{2}$ Although Williams' 
internalism about reasons has traditionally been interpreted as being motivated (at least in part) by a Humean conception of motivation, by suggesting that beliefs can motivate in their own right, Williams seems to distance himself from the traditional Humean picture. However, Williams does not abandon Humeanism completely. He says:

A man who does believe that considerations of family honour constitute reasons for action is a man with a certain disposition to action, and also dispositions of approval, sentiment, emotional reaction and so forth. (Op. Cit.)

Now it is unclear what the connection is between having these dispositions and being motivated by a belief. On Williams' account, it seems that an agent's having the relevant dispositions constitutes at least a necessary condition for that agent's having motivating beliefs. But if this is so, it would be false, or at least grossly misleading to say that an agent's beliefs can motivate in their own right; rather, they do so with the help of the relevant dispositions. The mechanisms Williams explicitly mentions certainly have a non-cognitivist ring to them: 'approval', 'sentiment', and 'emotional reaction' are concepts usually associated with Hume and non-cognitivism. However, dispositions cannot, in any ordinary sense of the word, be called desires. Dispositions are not intentional states like desires; i.e. they do not have content - they are not about anything. $^{3}$

As far as I can see, cognitivists need not disagree with any of this. Cognitivists can admit that beliefs are not, strictly speaking, capable of motivating in themselves. In order for a belief to motivate, they could argue, we would have to be such that when we come to have the relevant beliefs, we would be motivated to act on them. But this disposition need not be understood as a desire. (Cf. Parfit, and Broome) On the contrary, according to some philosophers, having the disposition to 
act in accordance with one's normative beliefs is simply what being (practically) rational consists in. (Scanlon, pp. 22-30.)

According to Williams' proposal, since beliefs about what reasons we have can have motivational force, beliefs about what reasons we have can be members of an agent's subjective motivational set. More significantly however, as MI tells us, if a belief is a member of an agent's motivational set, this motivating belief can also provide an agent with a normative reason to act; i.e. these beliefs can actually ground true reasons statements about the agent who entertains them.

\section{The strange case of Owen Wingrave}

Let us now apply Williams’ cognitivist proposal to the story of Owen Wingrave (which Williams has borrowed from Henry James). In the original story Owen has no desire whatsoever to join the army. His family, on the other hand, insist that considerations of family tradition and honour provide him a reason to join the army. Owen's family know full well that he has no desire to join the army (i.e. Owen has nothing in his motivational set to which the reasons statement could be appropriately linked), so when they say he has a reason to join the army, they take an externalist view about reasons. Suppose we change the story so that Owen has now come to believe that he has a reason to join the army because his family tradition bids him to do so; and, as a result, his is now motivated to join the army. If Williams and MI+CM are correct, it is now true of Owen that he has a reason to join the army. This may seem relatively straightforward. Consider the following two cases:

Case 1: (a) Owen believes that [the fact that family tradition bids Owen to join the army gives Owen a reason to join the army].

(b) Owen's belief in 1(a) motivates him to join the army. So, according to $\mathrm{MI}+\mathrm{CM}$ 
(c) Owen has a reason to join the army. ${ }^{4}$

Case 2: (a) Owen believes that [the fact that family tradition bids Owen to join the army gives Owen a reason to join the army].

(b) Owen's belief in 2(a) does not motivate him to join the army. So, according to $\mathrm{MI}+\mathrm{CM}$

(c) Owen does not have a reason to join the army.

According to MI+CM, Case 1 and Case 2 are correct descriptions of Owen and the reasons he would have in those cases. However, according to FB (the 'no reasons from false belief' proviso), since motivation resulting from false belief cannot give rise to reasons, it follows that if 1(c) is true, Owen's belief in 1(a) must be true. But in virtue of what is Owen's belief true? 'Because it motivates him!' seems to be the only answer; i.e. because of the fact correctly reported by 1(b). What about case 2? If 2(c) is true that must be because Owen's belief fails to motivate him. But this in turn implies that Owen's belief in 2(a) is false. And furthermore, Owen's belief in 2(a) is false because it fails to motivate him - false, that is, because 2(b) is true.

What we end up with if Williams and MI+CM are correct, I think, is the thesis that when an agent's relevant factual beliefs are correct, his beliefs about what reasons he has are true when and because they motivate him, and false when and because they fail to motivate him. ${ }^{5}$ Let us sum up this thesis as:

(TM): $\quad$ A normative belief's resulting motivation is that belief's truth-maker. ${ }^{6}$ 
Consider next

Case 3: (a) Owen believes that [the fact that family tradition bids Owen to join the army gives Owen a reason to join the army independently of what Owen is motivated to do].

(b) Owen's belief in 3(a) motivates him to join the army.

So, according to $\mathrm{MI}+\mathrm{CM}$

(c) Owen has a reason to join the army.

Does Owen really have a reason to join the army in Case 3? If the answer is yes - that is, if 3(c) is true, then, given FB it follows that Owen's belief in 3(a) is true. But if this is so, it follows trivially that 'Owen has a reason to join the army independently of what he is motivated to do' is true. But this of course is nothing short of externalism! Supporters of MI+CM cannot get around this problem by saying that Owen's belief in 3(a) is made true by his being motivated by that belief since this would imply a contradiction. Owen believes that it is the fact that family tradition bids him to join the army which makes it true that he has a reason to join the army; he doesn't believe that it is his being motivated by this belief that makes it true that he has a reason to join the army.

Obviously, the MI+CM theorist must say that Owen's belief in 3(a) is false. But if this is so, it seems he must reject TM. Since Owen is motivated by his normative belief even though this belief is false, his being motivated by it obviously does not make the belief true; i.e. his normative belief's motivational output is not that belief's truth-maker. If this principle is given up, however, it appears the MI+CM theorist will be at a loss to explain why, as he would have us believe, Owen has a reason to join the army in Case 1 and not in Case 2. The challenge for the MI+CM theorist, therefore, is to find some way to allow TM in Case 1 and Case 2, but not in Case 3. But perhaps he can meet this challenge. He may argue as follows: the reason why TM should be allowed in Case 1 and Case 2 but not in Case 3 is that Owen’s 
belief in 3(a) is false: it is dependent on a false belief - namely the belief that some facts are reason-giving independently of motivational considerations; false, in other words, because it violates FB. Owen's beliefs in 1(a) and 2(a) do not violate FB and so the truth and falsity of these beliefs do depend on whether or not they are motivationally efficacious.

The problem with line of argument, of course, is that it overlooks the fact that Owen's beliefs in Case 1 and Case 2 also display externalist commitments. If we look more closely at the content of Owen's beliefs in these cases we can see that what he actually believes is that it is the fact that his family tradition bids him to join the army that gives him a reason to join the army - he does not believe that he has this reason because he is motivated to act on considerations of family tradition. The consequence of all this is that the proposition 'Owen has a reason to join the army' is false in all three cases. So what does this show? Well, it shows at least that the MI+CM theorist will be wise to reject Williams’ suggestion that someone who believes that a particular consideration, external to his $S$, provides a reason to act thereby has an 'appropriate motivation in his $S$ '. This does not, however, show that internalists about reasons for action are committed to Humeanism about motivation. It seems internalists can still maintain that the following cases are possible:

Case 4: (a) Owen believes that family tradition bids Owen to join the army.

(b) Owen's belief in 4(a) motivates him to join the army.

So,

(c) Owen has a reason to join the army.

Case 5: (a) Owen believes that family tradition bids Owen to join the army.

(b) Owen's belief in 5(a) does not motivate him to join the army. So, 
(c) Owen does not have a reason to join the army.

Since the MI+CM theorist can consistently say that 4 and 5 are possible, he can also retain the conviction that the Humean theory of motivation is false - since 4 is a case in which a purely cognitive state motivates Owen. Furthermore, he can say all this while consistently maintaining that MI, FB, and TM are all true, provided we think of TM as being constrained by FB.

The upshot of this, however, is that the MI+CM theorist is committed to holding that while

(A) If Owen believes that [family tradition bids him to join the army] and this belief motivates him to join the army, then he has a reason to join the army

is true

(B) If Owen believes that [he has a reason to join the army because family tradition bids him to join the army] and this belief motivates him to join the army, then he has a reason to join the army

is false. But this seems extraordinary! Owen is motivated to join the army in both cases, and the only difference between them is that the contents of Owen's belief has shifted from [p] in A to [q because p] in B. Yet the MI+CM theorist is forced to say that A is true and B is false. This, I maintain, is deeply counter-intuitive.

The MI+CM theorist might try to get round this problem by saying that $\mathrm{B}$ is misleading. The thought may be that Owen's belief in B is a complex belief consisting of the following two elements: $[\mathrm{p}]=$ family tradition bids Owen to join the army, and [q because $\mathrm{p}]=$ Owen has a reason to join the army because family tradition bids Owen to do so. It might then be claimed that what really does the motivating in B is [p] alone, not [q because p], and if this is so, the MI+CM theorist might argue, 
Owen really does have a reason to join the army in B, and MI+CM gets it right. This answer is not convincing. Although Owen's being motivated by his complex belief in B is, admittedly, a bit odd, there's no contradiction involved in supposing that Owen is actually motivated by his belief [q because p], and conceptual space should certainly be reserved for this possibility. For instance, we could imagine that, as Williams would say, Owen has a 'pattern of emotional reaction' such that he is always motivated only by what he takes to be bona fide external reasons; or that Owen's 'disposition of evaluation' is such that when he believes he has a reason to do something, he believes this, at least in part, because he believes this reason obtains independently of his being motivated by it. If this is a genuine possibility (which it certainly seems to be), then Owen’s 'externalist commitments' (expressed in part by his belief in [q because p]) are central to his motivational set. Denying that beliefs of this kind can motivate does not seem like a plausible move. In a sense, it would seem unsatisfactory from an internalist point of view to deny this. If beliefs can motivate, then so can beliefs of the kind Owen has in B. The challenge remains then: if internalists want to maintain that MI is compatible with CM, they must provide us with some principled reason why A is true and B false - a reason which does not depend on some implausible view about which beliefs can motivate and which ones cannot. Needless to say, I am very doubtful that this challenge can be met.

\section{Conclusion}

In general, propositions of the form 'The fact that $\mathrm{p}$ gives $\mathrm{A}$ a reason to $\phi$ ' (which is the kind of proposition Williams considers in the passage quoted above) must be construed as external reasons statements. ${ }^{7}$ And as such, they cannot ground internal reasons statements - even if they motivate - on pain of (something close to) incoherence. Even if a proposition of the form just mentioned is true on an internalist reading - e.g. if 'p' refers to what A is or would be motivated to do - and even if such a proposition motivates an agent, it is hardly going to be made true by its motivating 
power (if it has any). Rather, such propositions are more likely to be mere restatements of the internalist thesis (MI) itself.

If internalists about reasons try to show that $\mathrm{MI}$ is compatible CM, they will run into the problems outlined in this paper. This, I believe, provides internalists with sufficient reason to reject Williams’ proposal and align themselves with the only theory of motivation which makes sense for them, namely Humeanism. 


\section{Notes}

${ }^{1}$ See also Williams' 'Internalism and the Obscurity of Blame', 'Replies', and 'Postscript: Some Further Notes on Internal and External Reasons'.

${ }^{2} \mathrm{An}$ interesting question is whether we can actually draw a clear distinction between motivating and non-motivating beliefs. We may even be sceptical about the existence of non-motivating beliefs. According to some dispositional theories of belief, A's believing that p consists in (among other things) A's being disposed (motivated) to infer q if A also believes $\mathrm{p} \rightarrow \mathrm{q}$; A's being motivated to give up his belief that $\mathrm{p}$ if presented with good evidence for not-p; A’s being motivated to assert p if sincere etc. But if this is correct, if beliefs essentially have this motivational aspect, then all of an agent's beliefs would be in his S. The same point might be generalised to include all mental states that can be given a dispositional analysis.

${ }^{3}$ It is of course possible to read Nagel's idea into the passage quoted from Williams. On such a reading, an agent's being a man with a certain disposition to action, approval, sentiment and emotional reaction simply follows from his being motivated by his belief that a particular consideration is a reason to act.

${ }^{4}$ For simplicity, I am going to assume throughout this paper that Owen has no other beliefs (or desires) that motivate him to join the army.

${ }^{5}$ It may of course be contentious to call it a 'fact' that Owen's family tradition 'bids' him to join the army. I shall simply ignore this complication.

${ }^{6}$ Here it is also natural to assume that a normative belief's failure to motivate should be taken as the truth-maker for the negation of the proposition which is the content of that belief. In other words, a normative belief's failure to motivate is that belief's 'false-maker' (if there are such things). 
${ }^{7}$ This is not to say that externalists are precluded from grounding reasons statements about an agent in that agent's S. Externalism, as I understand it, merely denies that reasons statements must be grounded in an agent's S.

\section{Bibliography}

Altham, J. E. J. and Ross Harrison (eds) (1995) World, Mind, and Ethics: Essays on the Ethical Philosophy of Bernard Williams (Cambridge: Cambridge University Press).

Broome, J. 'Reason and Motivation II’ (1997) in Proceedings of the Aristotelian Society Supplementary vol. 71, 131-146.

Millgram, E. (ed.) (2001) Varieties of Practical Reasoning (Cambridge, Mass: MIT Press).

Nagel, T. (1970) The Possibility of Altruism (Princeton: Princeton University Press).

Parfit, D. 'Reason and Motivation I' (1997) in Proceedings of the Aristotelian Society Supplementary vol. 71, 99-130.

Scanlon, T. (1998) What We Owe to Each Other (Cambridge, Mass: Harvard University Press).

Williams, B. (1981) 'Internal and External Reasons’, in his Moral Luck (Cambridge: Cambridge University Press).

Williams, B. 'Internalism and the Obscurity of Blame’ (1995) in his Making Sense of Humanity (Cambridge: Cambridge University Press).

Williams, B. (1995) 'Replies’ in Altham, J. E. J. and Ross Harrison (eds).

Williams, B. (2001) 'Postscript: Some Further Notes on Internal and External Reasons', in Millgram, E. (ed.). 